Journal of Social Sciences (COES\&RJ-JSS)

ISSN (E): 2305-9249 ISSN (P): 2305-9494

Publisher: Centre of Excellence for Scientific \& Research Journalism, COES\&RJ LLC

Online Publication Date: $1^{\text {st }}$ January 2015

Online Issue: Volume 4, Number 1, January 2015

http://www.centreofexcellence.net/J/JSS/JSS Mainpage.htm

\title{
THE INFLUENCE OF WORKPLACE CONDITION AND EMPLOYEE SATISFACTION ON EMPLOYEE COMMITMENT IN SOUTH AFRICAN
} COMPANIES

Elizabeth Chinomona

Vaal University of Technology

Faculty of Management Sciences

Vanderbijlpark, 1900

South Africa

Email: chakubvae@hotmail.com

Tebogo Mofokeng

Vaal University of Technology

Faculty of Management Sciences

Vanderbijlpark, 1900

South Africa

Email: mofokengtebogo@gmail.com

\author{
Abstract:
}

Developing and maintaining a relationship with employees has become an imperative thing to do for businesses to be competitive in today's dynamic environment. Workplace conditions tends to have either a positive or negative impact on employees' behaviour and output. Satisfied employees are likely to be more productive and involved in organisational activities. Committed employees are more likely to facilitate the provision of superior service quality. Despite the increase in research focusing on workplace conditions on organisational performance, there seem to be lack of studies that have investigated the influence of workplace conditions and employee satisfaction on employee commitment in the business fraternity in South Africa. Examining the influence of workplace conditions and employee satisfaction on employee commitment will be valuable in proving useful insights for businesses on how to create strong relationships with employees in order to enhance loyalty, longevity and competitiveness in the business. Therefore, using a data set of 150 from lower level employees in the Gauteng Province of South Africa, this study examines these relationships. Smart PLS software for Structural Equation Modeling (SEM) technique was used to statistically analyse the measurement and structural models. The results indicated that there is a significant positive relationship between all the three hypotheses. The research paper discusses both academic and managerial implications of the results and future research directions are suggested.

Keywords:

Behavioural decision making theory, Workplace conditions, employee satisfaction and employee commitment.

\section{Citation:}

Chinomona, Elizabeth; Mofokeng Tebogo (2015), The influence of workplace condition and employee satisfaction on employee committee in South African Companies; Journal of Social Sciences (COES\&RJ-JSS), Vol.4, No.1, pp: 649-663.

http://dx.doi.org/10.17632/xhkymxtr9s.1 


\subsection{INTRODUCTION}

Survival and success is important for any firm operating within the competitive business environment. As competition plays a major role in the business environment (Kocoglu, Imamoglu, Ince \& Keskin, 2011), committed employees become critical in ensuring that organisations remain competitive (Matzler \& Renzl, 2007). Commitment entails that employees are emotionally attached (Thomson, de Chernatony, Arganbright \& Khan, 1999) and as such they are more likely to be more engaged (Morgan \& Hunt, 1994) on organisational activities necessary for a firm's survival. While this assertion is significant or an aspiration for most firms, it is however worrisome that globally, only 31 percent of employees, appear to be engaged (Blessingwhite, 2011). It is therefore due to such predicaments that this study finds it necessary to investigate the factors influencing employee commitment. Particularly, the study seeks to identify if whether the conditions at the workplace affect employee satisfaction and hence their commitment.

While there is extensive knowledge of abundant key determinants of an organisation's success, employee commitment still remains pertinent (McGregor, 2009; Bingham \& Galagan, 2009). However what is of concern is that in view of the aforementioned statistic it appears that the standard of employee commitment for most firms is by and large distressing. In developing countries such as South Africa, the importation of outdated technologies, equipment and chemicals without the accompanying of guidelines to facilitate safety during application is a known phenomenon (Mbakaya, Onyoyo, Lwaki \& Omondi, 1999). These unpleasant workplace conditions may conflict with employee commitment (Wibberley, 2013) and presumably be in part, the reason employee satisfaction is a major concern for businesses today (Needleman 2011). Negative and unsupportive organisational climates decrease satisfaction, resulting in unfavourable outcomes (Wangenheim, Evanschitzky \& Wunderlinch, 2007) most likely to deter commitment. It is against this mainstay that the current study is found essential.

According to Bowen, (2010), "customer satisfaction and financial success often accompany positive organisational cultures". Satisfied employees are likely to be more productive and involved in organisational activities (Yoon \& Suh, 2003; Yee, Yeung \& Cheng, 2008) and committed employees are more likely to facilitate the provision of superior service quality (Bowen \& Ostroff, 2004; de Chernatony \& Cottam, 2009). It is therefore evident that satisfaction as well as commitment is vital for increasing organisational performance (Matzler et al., 2007; Chena, Lee \& Tseng, 2012).

As such, the academic literature is rife with studies on the drivers for employee satisfaction and commitment, respectively (e.g., Chi \& Gursoy, 2009; Wallace, de Chernatony \& Buil, 2013). According to Balmer, (2001) employee commitment is essential for accomplishing organisational objectives. It expresses the importance of the relationship between an employee and an organisation (Klein, Molloy \& Brinsfield, 2012) as well as drives the will to sacrifice short term goals in order to realize long-term goals (Anderson \& Weitz, 1992). However, satisfaction is presumed to be an influential construct of commitment (Beatson, Coote, \& Rudd, 2006) but this relation has been given little attention in academic works. Also according to Chena et al., (2012) workplace conditions influence employee satisfaction in some way but research on the influence of workplace condition on employee commitment remains scant as well.

As such, in order to fill the aforementioned research gap, the study has three empirical objectives, that is:

1.To investigate the influence of workplace condition on the satisfaction of employees working in Vanderbijlpark-South Africa. 
2.To investigate the influence of employee satisfaction on the commitment of employees working in Vanderbijlpark-South Africa.

3.To investigate the influence of workplace condition on the commitment of employees working in Vanderbijlpark-South Africa

This study is set to improve on our understanding of how organisational climate and employee emotional state play a role on employee commitment. In addition, a contribution of new knowledge and empirical support will be added to existing body of literature on employee commitment.

The rest of the paper is organized as follows. A research model and hypotheses are provided. A discussion on the methodology, constructs and scales is to follow and the analysis and conclusion is outlined thereafter.

\subsection{LITERATURE REVIEW}

This study will reveal literature on the four key words which are behavioural decision making theory, workplace condition, employee satisfaction and employee commitment.

\subsection{Behavioural decision making theory}

According to the behavioural decision making theory, employee perception of uncertainty affects their judgment significantly (Kahneman, Slovic \& Tversky, 1982). Schweizer and Patzelt, (2012) suggest that the decision of an employee to continue working for a firm depends on the extent of insecurity they perceive to be related to continued commitment. As employee commitment is essential for organisations (Bowen et al., 2004; Boyd \& Sutherland, 2006) employees need not encounter any organisational obstacles and must be satisfied (Aquino \& Thau, 2009; Bowling \& Beehr, 2006; Yee, et al., 2008) in order to encourage commitment. This suggests that when employees work in good conditions, they are more likely to be satisfied and hence be committed to their work. However, according to the behavioural decision making theory, when the organisational climate does not support employees in terms of addressing their concerns and providing necessary information and knowledge with regards to their role in achieving organisational goals (Schweiger \& DeNisi, 1991), employees might perceive uncertainty and as a result their level of satisfaction and involvement in the work environment decreases, leading to a reduction of commitment to the firm as well (Schweizer et al., 2012). Firms therefore need to create the often preferred convenient and expected organisational structure that will minimise the perception on uncertainty (Homburg \& Stock, 2004; McMullen \& Shepherd, 2006), thus building employee satisfaction and encouraging commitment.

\subsection{Workplace condition}

"Workplace condition" is a unidimensional construct and for the purpose of this study, a definition of workplace condition will be adopted from Hills and Joyce, (2013) where they suggest that workplace condition may be considered in terms of both the physical and cultural setting that shapes the psychosocial environment in which work is organised and performed. According to Howell and Annansingh, (2013), an inadequate supply of information and lack of communication restrains employees from fulfilling their duties better. In terms of safety, lack of awareness leads to unsafe work (Mbakaya et al., 1999) leading to workplace accidents that result in not only lost working time, but fatality as well (Boone, van Ours, Wuellrich \& Zweimuller, 2011). More so, Barish, (2001) discovered that in some cases these fatalities are caused by other individuals in the workplace as opposed to inanimate working objects and conditions. Although Weiss, (1999) and Hills et al., (2013) studied "workplace condition" within the context of teaching and medicine, it is considered as an influential component in the business environment as well (Mishima, Goto, Kubota \& Nagata, 2006; Cottini, Kato \& Westergaard-Nielsen, 2011) 


\subsection{Employee satisfaction}

Employee satisfaction is defined as "a pleasurable or positive emotional state resulting from the appraisal of one's job or job experiences" (Locke, 1976). In this study, a definition will be adopted from Robbins, (1996) where he describes the construct as an individual's broad outlook toward his or her work that has an effect on their productivity and competence in the workplace. Previous studies have provided support on the association of employee satisfaction with customer satisfaction and firm performance (Brown \& Lam, 2008; Wangenheim et al., 2007; Snipes, Oswald, LaTour \& Armenakis, 2005; Jung \& Yoon, 2013), and as such organisations strive to endorse employee satisfaction in order to respond effectively to the pressures of the competitive environment (Yee, et al., 2008). According to Lam, Zhang, and Baum, (2001) employee satisfaction is especially important in the service industry, however organisations in general need to actively promote it through discouraging issues negatively affecting employees such as low pay and limited upward mobility for example (Katzenbach \& Santamaria, 1999; Osterman \& Shulman, 2011; Segal, 2012). In this way, employees will be happy, displaying a pleasant attitude towards customers and thereby encouraging a positive perception of customers or clients regarding the firm and the particular services they provide (Howard \& Gengler, 2001).

\subsection{Employee commitment}

Commitment is defined as "an implicit or explicit pledge of relational continuity between exchange partners" (Dwyer et al., 1987). Moorman, Zaltman and Deshpandé, (1992) defined the term as "an enduring desire to maintain a valued relationship". It is a multidimensional construct comprising of affective, continuance and normative commitment however for the purpose of this study, it will be measured as unidimensional. Adopted from Schweizer et al., (2012) this study defines employee commitment as the employees' decision to stay with a firm regardless of the organisational climate or the change therein. According to Klein et al., (2012) commitment conveys the significance of a relationship between partners and their will to proceed with the relationship in the future. However when employees sense uncertainty, their will to continue working for the firm dissolves (McMullen \& Shepherd, 2006; Bockerman \& Ilmakunnas, 2009). Changes in organisational structures and working conditions arouse uncertainty (Shanley \& Correa, 1992), however when a firm devotes efforts to support employees, employees become dedicated to their work duties (Berry, 2002). Dedicated and committed employees become more willing and capable of delivering higher levels of service quality (Elmadağ, Ellinger \& Franke, 2008; Lee, Nam, Park \& Kyung, 2006). As a result customers are more likely to be satisfied and loyal to the organisation (Beatson et al., 2006).

\subsection{CONCEPTUAL MODEL AND HYPOTHESES DEVELOPMENT}

Drawing from the theory, the extant literature from Health Economics, Management and Operations Management aforementioned, a conceptual model is developed in Figure 1. The model consists of three constructs, that is, two predictors - workplace condition and employee satisfaction and one outcome variable - employee commitment. Conceivably, workplace condition and employee satisfaction influences employee commitment. Detailed explanations of the associations between these constructs are provided in the hypotheses developed hereafter. 


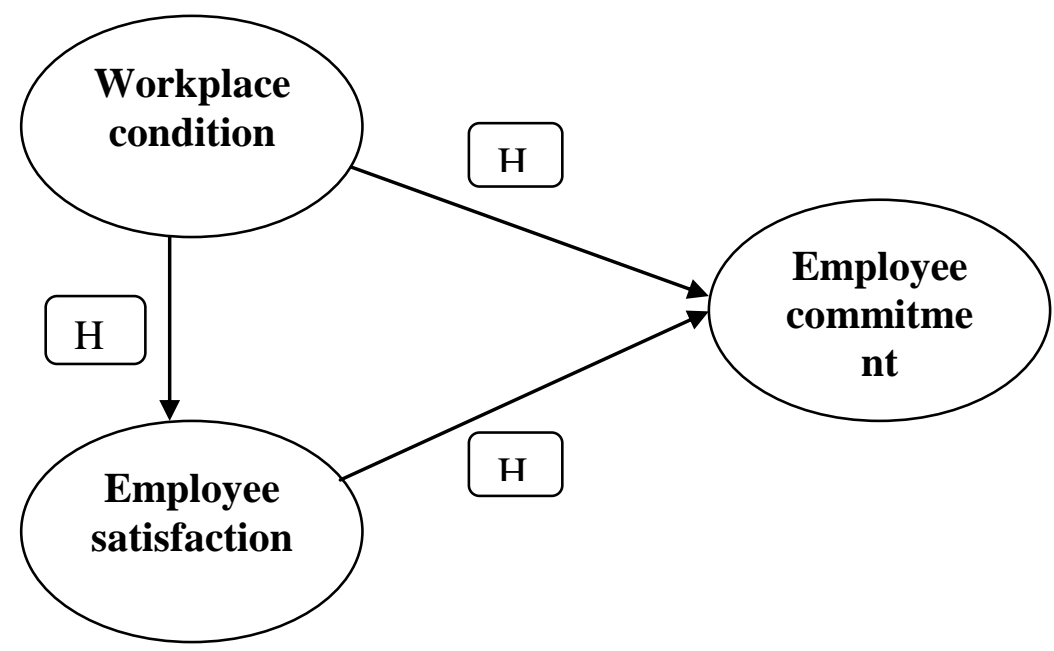

Figure 1: Conceptual Model

Based on the above literature and conceptual model, the following hypotheses are developed

\subsection{Workplace Condition and Employee Satisfaction}

According to the behaviour decision making theory, when firms support and care for their employees' through effective communication (e.g. demonstrating safety awareness) (Schweiger et al., 1991), employees are likely to be satisfied (Schweizer et al., 2012). More so, the assigning of apposite workload, the provision of opportunities and training and involvement in decision making are vital for employee satisfaction (Weiss, 1999). Therefore once the overall conditions at the workplace are in accordance with the South African labour legislations, it is expected that employees will be much satisfied in their workplace. Therefore, based on such reasoning, this paper hypothesizes that:

H1: Workplace condition has a positive influence on the satisfaction of employees working in Vanderbijlpark.

\subsection{Employee satisfaction and Employee commitment}

In an industry survey conducted by Mercer LLC 2010, results revealed that employee satisfaction is still a major concern for customers and firms alike (Needleman, 2011). It is therefore proposed in the current study that the development of positive working climates by firms will lead to satisfied employees (Wangenheim et al., 2007). Accordingly, when employees are satisfied, they develop a positive attitude and become more efficient (Robbins, 1996). This suggest that when employees become satisfied, they become happy (Chena et al., 2012) and as they become happy, they tend to be more dedicated and thus committed to their work (Yoon et al., 2003). Therefore, it can be hypothesized that:

H2: Employee satisfaction has a positive influence on the commitment of employees working in Vanderbijlpark.

\subsection{Workplace Condition and Employee Commitment}

According to Barish, (2001) many occupations are inherently risky. As such many workers are likely to be involved in a workplace accident (Boone et al., 2011). Furthermore, it has been found that unsupportive workplace conditions are the primary reason why employees tend to leave their work (Yee, 1990; Cottini et al., 2011). It is therefore submitted in the current study that safety awareness programmes and supportive 
workplace conditions must be arranged within organisations in order for employees to be contented (Yee, 1990; Mbakaya et al., 1999). Accordingly, when employees work under such a positive working climate, they are likely to be more committed to their work. Thus, based on such reasoning, this paper hypothesizes that:

H3: Workplace condition has a positive influence on the commitment of employees working in Vanderbijlpark.

\subsection{Research Methodology}

\subsection{Sample and data collection}

The target population for the study was South African companies in Gauteng province. The sampling unit was the individual employees who are not in managerial positions. This method has the advantage of speed, is less costly and the researcher has control over respondent type. Students from the Vaal University of Technology were recruited as research assistants to distribute and collect the questionnaires. Of the total of 200 questionnaires distributed, 150 usable questionnaires were retrieved for the final data analysis, representing a response rate of 75 per cent. To eliminate differences in response patterns due to different reference points, all respondents were prompted to answer the questionnaires with reference to companies they work for.

\subsection{Measurement Instrument and Questionnaire Design}

Research scales were operationalized on the basis of previous work. Proper modifications were made in order to fit the current research context and purpose. "Workplace conditions" measure used four-item scales adapted from Gule (2009). "Employee satisfaction" used four- item scale measure all adapted from Chinomona, Lin, Wang and Chen (2010). "Employee commitment" used five -item scale measure adapted from Meyer, Allen and Smith (1993). All the measurement items were measured on a five-point Likert-type scales that was anchored by $1=$ strongly disagree to $5=$ strongly agree to express the degree of agreement.

\subsection{Respondent Profile}

Table 1 presents the description of the participants. The respondents were asked to report their demographic information, including gender, age, position in the company and type of employment. The respondents were predominantly females (86\%). The mode age group of the respondent was that of less than 36-45 years (50\%). $70 \%$ occupy the junior level positions. $75 \%$ of the respondents were part-time employees.

Table 4.1 Sample Demographic Characteristics

\begin{tabular}{|l|l|l|}
\hline Gender & Frequency & Percentage \\
\hline Male & 64 & 43 \\
\hline Female & 86 & 57 \\
\hline Total & $\mathbf{1 5 0}$ & $\mathbf{1 0 0}$ \\
\hline Age & Frequency & Percentage \\
\hline $18-25$ & 20 & 13 \\
\hline $26-35$ & 30 & 20 \\
\hline $36-45$ & 50 & 33 \\
\hline $46-55$ & 35 & 23 \\
\hline 56 and above & 15 & 11 \\
\hline
\end{tabular}


The influence of workplace condition and employee satisfaction ...

\begin{tabular}{|l|l|l|}
\hline Total & $\mathbf{1 5 0}$ & $\mathbf{1 0 0}$ \\
\hline Position in the company & Frequency & Percentage \\
\hline Trainee entry level & 15 & 10 \\
\hline Junior level & 70 & 47 \\
\hline Senior level & 55 & 37 \\
\hline Others (Specify) & 10 & 6 \\
\hline Total & $\mathbf{1 5 0}$ & $\mathbf{1 0 0}$ \\
\hline Type of employment & Frequency & Percentage \\
\hline Casual & 20 & 13 \\
\hline Contract & 35 & 23 \\
\hline Part-Time & 75 & 51 \\
\hline Permanent & 20 & 13 \\
\hline Total & $\mathbf{1 5 0}$ & $\mathbf{1 0 0}$ \\
\hline
\end{tabular}

\subsection{Data Analysis}

In order to statistically analyze the measurement and structural models, this study used Smart PLS software for Structural Equation Modeling (SEM) technique (Ringle, Wende \& Will 2005). In SEM, the measurement model refers to the linkages between the latent variables and their manifest variables and the structural model captures the hypothesized causal relationships among the research constructs (Chin \& Newsted, 1999; Wetzels, Odekerken-Schroder \& Van Oppen, 2009). Unlike AMOS and LISREL which are covariance based approaches, Smart PLS is a regression based technique that originates from path analysis. Smart PLS has emerged as a powerful approach to study causal models involving multiple constructs with multiple indicators (Chinomona \& Surujal, 2012). Smart PLS - a component-based method, has an ability to model latent constructs that are uncontaminated by measurement error under conditions of non-normality. It has the ability to handle complex predictive models in small-to-medium sample sizes. Since the current study sample size is relatively small (150) Smart PLS was found more appropriate and befitting the purpose of the current study. In this respect, Bootstrapping resampling method was used to test the statistical significance of the relationships. This procedure entailed generating 200 sub-samples of cases randomly selected, with replacement, from the original data. Below is Table 5.1, presenting evidence on the reliability and validity of the measurement model.

\subsection{Measurement Model}

To ensure convergent validity, the researcher checked if items loaded on their respective (a priori) constructs with loadings greater than 0.6, while discriminant validity was checked by ensuring that there was no significant inter-research variables cross-loadings (Chin, 1998). As can be seen (Table 5.1), all items have loadings greater than 0.6 (i.e. ranging from 0.640 to 0.891 ), with no cross-loadings greater than 0.903 , while t-statistics derived from bootstrapping (200 resamples) suggest all loadings are significant at $p$ value, 0.001. As such, this confirms that all the measurement items converged well on their respective constructs and therefore are acceptable measures. 
Journal of Social Sciences (COES\&RJ-JSS), 4(1), pp. 649-663

Table 5.1 Accuracy Analysis Statistics

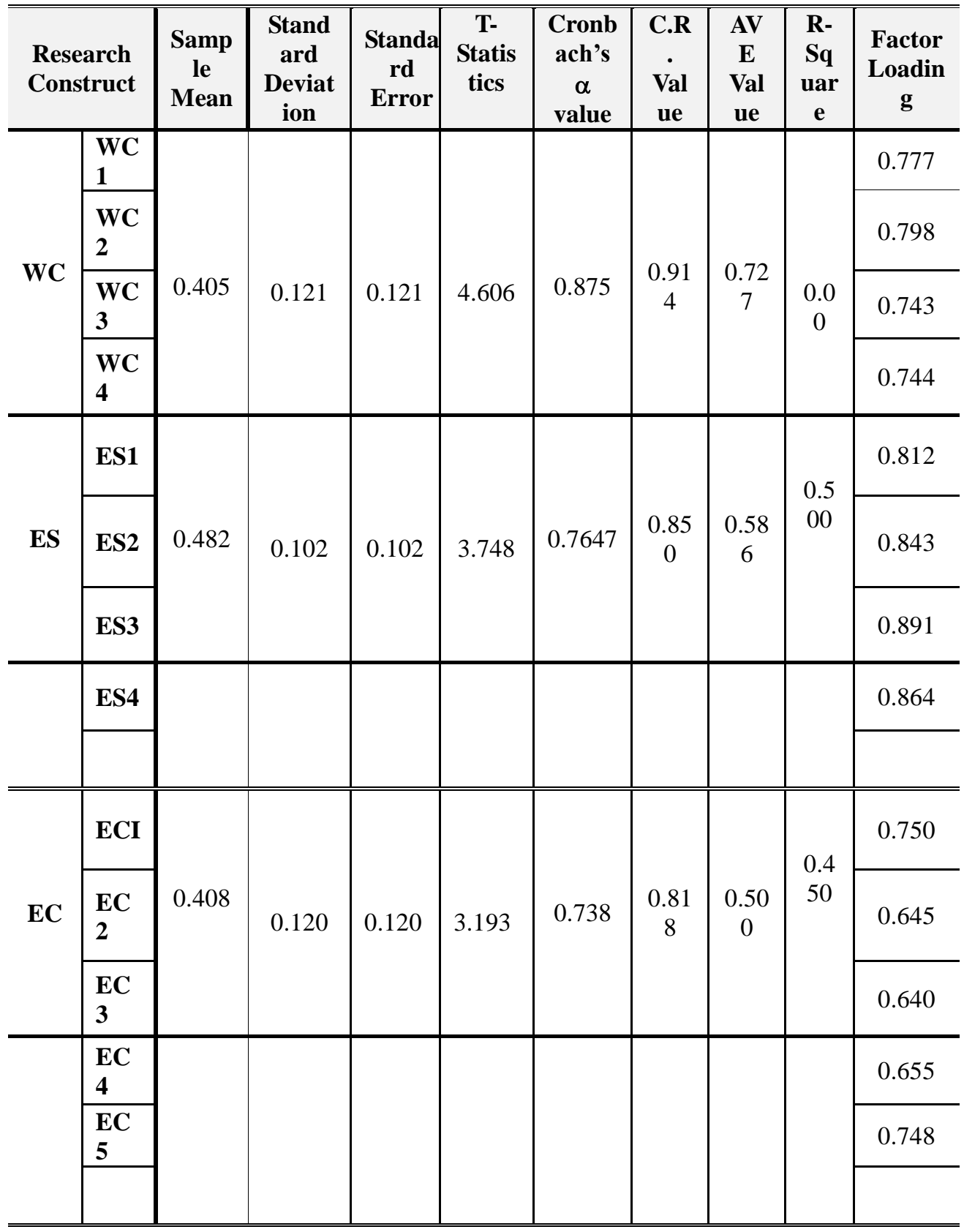

Note: EC=Employee Commitment $\quad$ ES=Employee Satisfaction; WC=Worplace Condition; C.R.: Composite Reliability; AVE: Average Variance Reliability; * Scores: 1 - Strongly Agree; 3 -Neutral; 5 - Strongly Disagree 
According to Chin (1998), research variables should have an average variance extracted (AVE) of more than 0.5 and a composite reliability of more than 0.8 (convergent validity), and inter-construct correlations should be less than the square-root of the AVE (discriminant validity). As can be seen (Table 2), all constructs exceed these criteria, with AVE and CR generally equal or greater than 0.5 and 0.8 , respectively. All in all, these results confirm the existence of discriminant validity of the measurement used in this study.

\section{Table 5.2 Correlations between Constructs}

\begin{tabular}{|l|l|l|l|}
\hline Research Constructs & EC & ES & WP \\
\hline EC & 1.000 & & \\
\hline ES & 0.460 & 1.000 & \\
\hline WP & 0.334 & 0.400 & 1.000 \\
\hline Note: EC=Employee Commitment; ES=Employee Satisfaction; WP=Worplace
\end{tabular}

Condition.

\subsection{Path Model}

PLS also generates the path coefficients for the relationships modelled among the constructs. The significance of these coefficients was assessed using the bootstrap procedure (with 200 sub-samples) that provided the t-values for each path estimate. Figure 5.1 and Table 5.3 presents the results of the PLS analysis on the structural model along with the path estimates and t-values. Support for the study hypotheses, which are labelled on their corresponding paths in Figure 5.1, could be ascertained by examining the directionality (positive or negative) of the path coefficients and the significance of the tvalues. The standardized path coefficients are expected to be at least 0.2 , and preferably greater than 0.3 (Chin 1998).

Figure 5.1 Measurement and Structural Model

\section{Results}

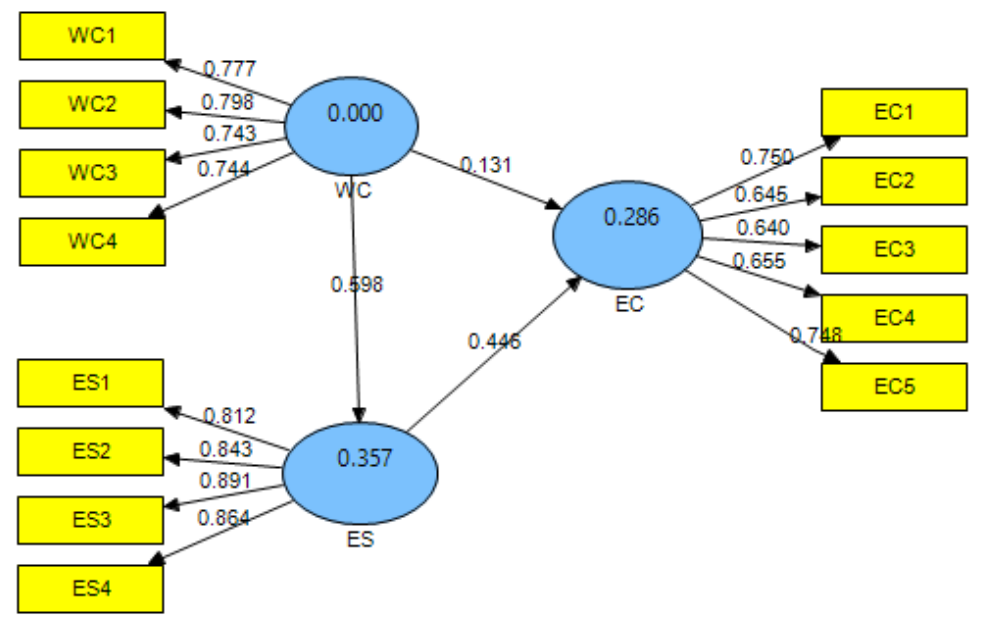

Note: EC=Employee Commitment $\quad$ ES=Employee Satisfaction; WC=Worplace Condition 
The results provide support for the proposed positive relationships between the three relationships (i.e. $\mathrm{H} 1, \mathrm{H} 2$, and $\mathrm{H} 3$ ). Figure 5.1 and Table 5.3 provide the path coefficients for $\mathrm{H} 1$ to $\mathrm{H} 3$ (i.e. 0.131 to 0.598 ).

Table 5.3 Results of Structural Equation Model Analysis

\begin{tabular}{|l|l|l|l|l|}
\hline $\begin{array}{l}\text { Proposed Hypothesis } \\
\text { Relationship }\end{array}$ & Hypothesis & $\begin{array}{l}\text { Path } \\
\text { Coefficients }\end{array}$ & T-Statistics & $\begin{array}{l}\text { Rejected/ } \\
\text { Supported }\end{array}$ \\
\hline WC to ES & $\mathrm{H} 1$ & 0.598 & 4.333 & Supported \\
\hline ES to EC & $\mathrm{H} 2$ & 0.446 & 4.836 & Supported \\
\hline WC to EC & $\mathrm{H} 3$ & 0.131 & 4.289 & Supported \\
\hline $\begin{array}{l}\text { Note: EC=Employee Commitment; ES=Employee Satisfaction; } \\
\text { Condition }\end{array}$
\end{tabular}

Following formulae provided by Tenenhaus, Vinzi, Chatelin \& Lauro, (2005), the global goodness-of-fit $(\mathrm{GoF})$ statistic for the research model was calculated. The calculated global goodness of fit $(\mathrm{GoF})$ is 0.66 , which exceed the threshold of $\mathrm{GoF}>0.36$ suggested by Wetzels, Odekerken-Schröder \& van Oppen (2009). Thus, this study concludes that the research model has a good overall fit.

\subsection{Discussion of Results}

The results in Table 5.3 and Figure 5.1 provide support for the three hypotheses (H1 to H3). Hypothesis 1 posited a positive relationship between workplace condition and employee satisfaction. Consistent with H1, the result in Table 5.3 and Figure 5.1, indicates that there is a significant $(\mathrm{t}=4.333)$ positive $(\mathrm{beta}=0.598)$ relationship between workplace condition and employee satisfaction. Therefore, $\mathrm{H} 1$ is supported.

Hypothesis 2 posited a positive association between employee satisfaction and employee commitment. Hypothesis 2, results indicated that the relationship between employee satisfaction and employee commitment (beta $=0.446$ ) is positive and that relationship is significant $(\mathrm{t}=4.836)$. This is consistent with the prediction of $\mathrm{H} 2$ and is therefore supported. Thus, a higher level of employee satisfaction is associated with a high employee commitment.

Hypothesis 3 posited a positive relationship between workplace condition and employee commitment. Consistent with $\mathrm{H} 3$, the result in Table 5.3 and Figure 5.1, indicates that there is a significant $(\mathrm{t}=4.289)$, positive $(\mathrm{beta}=0.131)$ relationship between workplace condition and employee commitment. Therefore, $\mathrm{H} 3$ is supported.

\subsection{Conclusion}

The purpose of this study was to investigate the influence of workplace conditions and employee satisfaction on employee commitment. To achieve this objective, this paper used Smart PLS to test the hypotheses. To test the proposed hypotheses, data were collected from Vanderbijilpark in Gauteng Province in South Africa. The empirical result supported all the three posited research hypotheses in a significant way. 


\subsection{Implications of the study}

The current study investigate this contentious issues in an often most neglected research context - the African setting. Therefore, the findings of this empirical study are expected to provide fruitful new insights and implications to both academicians and employees across the globe. In particular, the current study findings provide tentative support to the proposition that workplace conditions and employee satisfaction have an impact on employee commitment. On the practitioners' side, important influential role of workplace conditions and employee satisfaction on employee commitment in an African context are highlighted. Therefore, this study for instance submits managers should find ways to attract and please employees in order to retain them.

\subsection{Limitations and Future Research}

Although this study makes significant contributions to both academia and practice, it was limited in some ways, and therefore some future research avenues are suggested. First, the data were gathered from Vanderbijlpark in the Gauteng Province of South Africa and the sample size of 150 which is relatively small. Perhaps, the results would be more informative if the sample size is large and data gathered from the other eight provinces of the country are included. Therefore, future studies may be conducted by using data from other cities and other provinces in South Africa. Second, perhaps too, future studies should not be limited to South Africa, but rather consider extending this research to other African countries such as Zimbabwe for results comparison. Future studies can also extend the current study by studying the relationships in the current conceptual model in other sectors of the economy. Above and beyond, this will immensely contribute new knowledge to the existing body of literature in the African setting - a research context which happens to be neglected in academics.

\section{REFERENCES}

ANDERSON, E., \& WEITZ, B. 1992. The use of pledges to build and sustain commitment in distribution channels. Journal of Marketing Research, 29(1), 18-34.

AQUINO, K., \& THAU, S. 2009. Workplace victimization: Aggression from the target's perspective. Annual Review of Psychology, 60(1), 717-741.

BALMER, J.M.T. 2001. Corporate identity, corporate branding and corporate marketing: Seeing through the fog. European Journal of Marketing, 35(3/4), 248-291.

BARISH, R.C., \& CIH, M.S. 2001. Legislation and Regulations addressing Workplace Violence in the United States and British Columbia. American Journal of Preventive Medicine, 20(2), 149-154.

BEATSON, A., COOTE, L.V., \& RUDD, J.M. 2006. Determining consumer satisfaction and commitment through self-service technology and personal service usage. Journal of Marketing Management, 22(7), 853-882.

BERRY, L.L. 2002. Relationship marketing of services-Perspectives from 1983 and 2000. Journal of Relationship Marketing, 1(1), 59-70.

BINGHAM, T., \& GALAGAN, P. 2009. Training at Lowe's: Let's learn something together. $T+D, 34-43$.

BLESSINGWHITE, 2011. Employee Engagement Report, (retrieved on 12.08.13), [from http://www.blessingwhite.com/eee report.asp]. 
BOCKERMAN, P., \& ILMAKUNNAS, P. 2009. Job disamenities, job satisfaction, quit intentions, and actual separations: Putting the pieces together. Industrial Relations, 48(1), 73-96.

BOONE, J., VAN OURS, J.C., WUELLRICH, J-P., \& ZWEIMULLER, J. 2011. Recessions are bad for workplace safety. Journal of Health Economics, 30, 764-773.

BOWEN, D.E. 2010. Creating and Maintaining a Service Culture. In Ostrom, A. L., Bitner, M. J.,Brown,S.W.,Burkhard,K.A.,Goul,M.,SmithDaniels,V.,Demirkan,H.,\&Rabinovich, E. (2010). Moving forward and making a difference: Research priorities for the science of service. Journal of Services Research, 13(1), 4-36.

BOWEN, D.E. 1996. Market-focused HRM in service organizations: Satisfying internal and external customers. Journal of Market-Focused Management, 1(1), 31-48.

BOWEN, D.E., \& LAWLER, E.E. 1992. Total quality-oriented human resources management. Organizational Dynamics, 29-41.

BOWEN, D.E., \& OSTROFF, C. 2004. Understanding HRM-firm performance linkages: The role of the strength of the HRM system. Academy of Management Review, 29(2), 203221.

BOWLING, N.A., \& BEEHR, T.A. 2006. Workplace harassment from the victim's perspective: A theoretical model and meta-analysis. Journal of Applied Physiology, 91(5), 998-1012.

BOYD, G., \& SUTHERLAND, M. 2006. Obtaining employee commitment to living the brand of the organization. South African Journal of Business Management, 37(1), 9-20.

BROWN, S.P., \& LAM, S.K. 2008. A Meta-Analysis of Relationships Linking Employee Satisfaction to Customer Responses. Journal of Retailing, 84(3), 243-255.

CHENA, Y-H., LEE, W-C., \& TSENG, K-W. 2012. Differentiation Research on employee satisfaction and happiness for European invested and local Chinese companies. Procedia - Social and Behavioral Sciences, 57, 549-554.

CHI, C.G., \& GURSOY, D. 2009. Employee satisfaction, customer satisfaction and financial performance: An empirical examination. International Journal of Hospitality Management, 28, 245-253.

CHIN, W.W.1998. Issues and opinion on structural equation modelling, MIS Quarterly, $22(1), 7-16$.

CHIN, W.W \& NEWSTED P.R. 1999. Structural equation modeling analysis with small samples using partial least squares. In Rick Hoyle (ed). Statistical Strategies for Small Sample Research. Thousand Oaks, CA: Sage. pp. 307-341.

1. CHINOMONA, R., LIN, J.,WANG, M.,\&CHENG, J. 2010. Soft power and Desirable

2. Relationship Outcomes in Zimbabwe Distribution Channels. Journal of African Business, 11(2) :182-200.

CHINOMONA, R \& SURUJAL, B. 2012. The influence of student internship work experience on their self-improvement and professionalism in Sport Management. African Journal for Physical, Health Education, Recreation and Dance, 18(4), 885-899.

COTTINI, E., KATO, T., \& WESTERGAARD-NIELSEN, N. 2011. Adverse workplace conditions, high-involvement work practices and labor turnover: Evidence from Danish linked employer-employee data. Labour Economics, 18, 872-880.

DE CHERNATONY, L., \& COTTAM, S. 2009. Interacting contributions of different departments to brand success. Journal of Business Research, 62(3), 297-304. 
DWYER, R.F., SCHURR, P.H., \& OH, S. 1987. Developing buyer-seller relationships. Journal of Marketing, 51(2), 11-27.

ELMADAĞ, A.B., ELLINGER, A.E., \& FRANKE, G.R. 2008. Antecedents and consequences of frontline service employee commitment to service quality. Journal of Marketing Theory and Practice, 16(2), 95-110.

GULE. X. M. 2009. Thesis on Improving the service quality of Taxi operators in the Nelson Mandela Bay. Nelson Mandela Metropolitan University.

GUNDLACH, G.T., ACHROL, R.S., \& MENTZER, J.T. 1995. The structure of commitment in exchange. Journal of Marketing, 59(1), 78-92.

HILLS, D., \& JOYCE, C. 2013. A review of research on the prevalence, antecedents, consequences and prevention of workplace aggression in clinical medical practice. Aggression and Violent Behavior, 18, 554-569.

HOMBURG, C., \& STOCK, R.M. 2004. The link between salespeople's job satisfaction and customer satisfaction in a business-to-business context: a dyadic analysis. Journal of the Academy of Marketing Science, 32(2), 144-158.

HOWARD, D.J., \& GENGLER, C. 2001. Emotional contagion effects on product attitudes. Journal of Consumer Research, 28(2), 189-201.

HOWELL, K.E., \& ANNANSINGH, F. 2013. Knowledge generation and sharing in UK universities: A tale of two cultures? International Journal of Information Management, 33, 32-39.

JUNG, H.S., \& YOON, H.H. 2013. Do employees' satisfied customers respond with a satisfactory relationship? The effects of employees' satisfaction on customers' satisfaction and loyalty in a family restaurant. International Journal of Hospitality Management, 34, $1-8$.

KAHNEMAN, T., SLOVIC, P., \& TVERSKY, A. 1982. Judgement under uncertainty: Heuristics and biases. Cambridge, MA: Cambridge Press.

KATZENBACH, J.R., \& SANTAMARIA, J.A. 1999. Firing up the Front Line. Harvard Business Review, 77(3), 107-17.

KLEIN, H.J., MOLLOY, J.C., \& BRINSFIELD, C.T. 2012. Reconceptualizing workplace commitment to redress a stretched construct: Revisiting assumptions and removing confounds. Academy of Management Review, 37, 130-151.

KOCOGLU, I., IMAMOGLU, S.Z., INCE, H., \& KESKIN, H. 2011. The effect of supply chain integration on information sharing: Enhancing the supply chain performance. Procedia Social and Behavioral Sciences, 24, 1630-1649.

LAM, T., ZHANG, H., \& BAUM, T. 2001. An investigation of employee's job satisfaction: The case of hotels in Hong Kong. Tourism Management, 22, 157-165.

LEE, Y.K., NAM, J.H., PARK, D.H., \& KYUNG, A.L. 2006. What factors influence customer oriented prosocial behavior? Journal of Services Marketing, 20(4), 251-264.

LOCKE, E.A. 1976. The Nature and Causes of Job Satisfaction, in Handbook of Industrial and Organizational Psychology. Dunnatte Marvin ed. Chicago: Rand McNally, 1297-350.

MATZLER, K., \& RENZL, B. 2007. Assessing asymmetric effects in the formation of employee satisfaction. Tourism Management, 28, 1093-1103.

MBAKAYA, C.F.L., ONYOYO, H.A., LWAKI, S.A., \& OMONDI, O.J. 1999. A survey on management perspectives of the state of workplace health and safety practices in Kenya. Accident Analysis and Prevention, 31, 305-312.

MCGREGOR, J. 2009. When service means survival. Business Week Special Report on Extreme Customer Service, 26-40. 
MCMULLEN, J.S., \& SHEPHERD, D.A. 2006. Entrepreneurial action and the role of uncertainty in the theory of the entrepreneur. Academy of Management Review, 31, 132152.

MEYER, J.P. ALLEN, N.J \& SMITH. C. 1993. Commitment to organisations and Occupations: Extension and Test of a Three- Component Conceptuallisation. Journal of Applied Psychology, 78, 538-551.

MISHIMA, N., GOTO, T., KUBOTA, S., \& NAGATA, S. 2006. Present conditions and problems of applying autogenic training to promote mental health in the workplace. International Congress Series, 1287, 230-234.

MOORMAN, C., ZALTMAN, G., \& DESHPANDÉ, R. 1992. Relationships between providers and users of market research: The dynamics of trust within and between organizations. Journal of Marketing Research, 29(3), 314-329.

MORGAN, R.M., \& HUNT, S.D. 1994. The commitment-trust theory of relationship marketing. Journal of Marketing, 58, 20-38.

NEEDLEMAN, S.E. 2011. One-Third of U.S. Workers Ready to Quit, (retrieved on 09.08.2013), [from http://blogs.wsj.com/in-charge/2011/06/20/ one-third-of-u-s-workersready-to-quit/].

OSTERMAN, P., \& SHULMAN, B. 2011. Good Jobs America: Making Work Better for Everyone. New York: Russell Sage.

RINGLE CM, WENDE S \& WILL A. (2005). SmartPLS 2.0 M3. Available at http:// www.smartpls.de. Accessed 23/03/2013

ROBBINS, S.P. 1996. Organizational Behavior, Concepts Controversies Applications, Publisher: Prentice Hall, $7^{\text {th }}$ Edition.

SCHWEIGER, D.M., \& DENISI, A.S. 1991. Communication with employees following a merger: A longitudinal field experiment. Academy of Management Journal, 34, 110-135.

SCHWEIZER, L., \& PATZELT, H. 2012. Employee commitment in the post-acquisition integration process: The effect of integration speed and leadership. Scandinavian Journal of Management, 28, 298-310.

SEGAL, D. 2012. Apple's Retail Army, Long on Loyalty but Short on Pay (retrieved on 10.08.13), [from http://www.nytimes.com/ 2012/06/24/business/apple-store-workersloyal-but-short-on-pay.html? pagewanted=all\& r=0].

SHANLEY, M.T., \& CORREA, M.E. 1992. Agreement between top management teams and expectations for post acquisition performance. Strategic Management Journal, 13, 245-266.

SNIPES, R.L., OSWALD, S.L., LATOUR, M., \& ARMENAKIS, A.A. 2005. The effects of specific job satisfaction facets on customer perceptions of service quality: An employee-level analysis. Journal of Business Research, 58, 1330-1339.

TENENHAUS, M. VINZI, V. E. CHATELIN, Y.M \& LAURO, C. 2005. PLS Path Modeling. Computational Statistics and Data Analysis, 48(1), 159-205.

THOMSON, K., DE CHERNATONY, L., ARGANBRIGHT, L., \& KHAN, S. 1999. The buy-in benchmark: How staff understanding and commitment impact brand and business performance. Journal of Marketing Management, 15(8), 819-835.

WALLACE, E., DE CHERNATONY, L., \& BUIL, I. 2013. Building bank brands: How leadership behavior influences employee commitment. Journal of Business Research, 66, 165-171. 
WANGENHEIM, F.V., EVANSCHITZKY, H., \& WUNDERLINCH, M. 2007. Does the employee-customer satisfaction link hold for all employee groups? Journal of Business Research, 60, 690-697.

WEISS, E.M. 1999. Workplace condition Perceived workplace conditions and first-year teachers' morale, career choice commitment, and planned retention: A secondary analysis. Teaching and Teacher Education, 15, 861-879.

WETZELS, M. ODEKERKEN-SCHRÖDER, G \& VAN OPPEN, C. 2009. Using PLS path modeling for assessing hierarchical construct models: Guidelines and empirical illustration

WIBBERLEY, G. 2013. The problems of a dirty workplace in domiciliary care. Health and Place, 21, 156-162.

YEE, R.W.Y., YEUNG, A.C.L., \& CHENG, T.C.E. 2008. The impact of employee satisfaction on quality and profitability in high-contact service industries. Journal of Operations Management, 26, 651-668.

YEE, S.M. 1990. Careers in the classroom: When teaching is more than a job. New York: Teachers College Press.

YOON, M.H., \& SUH, J. 2003. Organizational citizenship behaviors and service quality as external effectiveness of contact employees. Journal of Business Research, 56(8), 597611. 